\title{
The Feasibility of Social Science Learning E-Book Contains Balinese Local Wisdom for Elementary School
}

\section{Ni Kadek Rosita Dewi ${ }^{1 *}$, Anak Agung Gede Agung²}

1,2 Ganesha University of Education, Singaraja, Indonesia

\author{
A R T I C LE IN F O \\ Article history: \\ 25 December 2020 \\ Received in revised form \\ 01 January 2021 \\ Accepted 25 January \\ 2021 \\ Available online 25 \\ February 2021

Kata Kunci:
E-Book, Kearifan Lokal
Bali, IPS
Keywords:
E-Book, Balinese Local
Wisdon, Social Science

\begin{abstract}
A B S T R A K
Hasil analisis kebutuhan media pembelajaran di Sekolah Dasar menunjukkan bahwa guru kurang memanfaatkan media pembelajaran yang inovatif selama pembelajaran online dan kurangnya penguatan nilai-nilai kearifan lokal di era globalisasi. Penelitian ini bertujuan untuk mengembangkan E-Book bermuatan nilai-nilai kearifan lokal Bali. Jenis penelitian ini adalah penelitian pengembangan dengan menggunakan model ADDIE (analyze, design, development, implementation, evaluation). Pengumpulan data digunakan metode kuesioner/angket dengan teknik analisis data yakni analisis deskriptif kuantitatif. Hasil validasi media E-Book berdasarkan penilaian ahli isi muatan pelajaran IPS diperoleh skor 87,50\% dengan kualifikasi baik, ahli desain instruksional diperoleh skor 100\% dengan kualifikasi sangat baik, ahli media pembelajaran diperoleh skor 92,50\% dengan kualifikasi sangat baik. Hasil uji pengguna perorangan pada 3 orang siswa diperoleh skor 93,33\% dengan kualifikasi sangat baik, dan hasil uji pengguna melalui uji kelompok kecil pada 12 orang siswa diperoleh skor 94,16\% dengan kualifikasi sangat baik. Berdasarkan hasil analisis data uji coba produk oleh para ahli dan hasil uji subjek pengguna disimpulkan bahwa media E-Book bermuatan nilai-nilai kearifan lokal Bali
\end{abstract} ini layak digunakan dalam pembelajaran muatan IPS di kelas IV Sekolah Dasar. Implikasi dari pengembangan E-Book ini memerlukan fasilitas penunjang seperti akses internet, komputer/laptop, handphone dan kemampuan guru atau siswa dalam mengakses E-Book.

\begin{abstract}
A B S T R A C T
The results of the analysis of the needs for learning media in elementary schools show that teachers do not use innovative learning media during online learning and there is a lack of strengthening the values of local wisdom in the era of globalization. This study aims to develop an E-Book with the values of Balinese local wisdom. This type of research is a development research using the ADDIE (Analyze, Design, Development, Implementation, Evaluation) model. Data collection used a questionnaire / questionnaire method with data analysis techniques, namely quantitative descriptive analysis. The results of E-Book media validation based on the expert's assessment of the content of social studies subject matter obtained a score of $87.50 \%$ with good qualifications, instructional design experts obtained a score of $100 \%$ with very good qualifications, learning media experts obtained a score of $92.50 \%$ with very good qualifications. The results of the individual user test on 3 students obtained a score of $93.33 \%$ with very good qualifications, and the results of the user test through a small group test on 12 students obtained a score of $94.16 \%$ with very good qualifications. Based on the results of product trial data analysis by experts and user subject test results, it is concluded that the E-Book media containing the values of Balinese local wisdom is suitable for use in learning social studies content in grade IV of Elementary Schools. The implication of developing this E-Book requires supporting facilities such as internet access, computers / laptops, cellphones and the ability of teachers or students to access E-Books.
\end{abstract}

\section{Introduction}

An education development cannot be separated with globalization influence, where science and technology grow rapidly (Amini, 2020). Various media and learning aids were made by human as a result of innovation in information and communication technology field (Budiyono, 2020). In this 21 st century, technology considered as a need in learning process, especially to motivate and gain students' interest during learning activity (Hidayat, 2020). Moreover, Coronavirus Disease (Covid-19) pandemic carried out the learning process into an online activity, then an online media is needed in order to support the learning process. Learning media is one of supporting components in order to achive a success learning process, especially during online learning. By using learning media students can increase their interest in 
the learning process (Supriyono, 2018). It is expected that learning media utilization can help to deliver a clear instruction, hence the purpose of the learning process can be achieved effectively and effeciently (Nurrita, 2018). Besides, learning media can also create more interesting learning process (Kuswanto \& Radiansah, 2018).

Based on the interview result conducted with teacher who taught $4^{\text {th }}$ grade elementary school students in SD No. 1 Jagapati, there were several problems found such as, lack of learning media utilization during an online learning, because the teacher only sticked on the textbook provided by school, specifically for social sciences lesson content (IPS). The book which was used basically describe and tell more about other regions, because the extended material contained in the book. Then, the learning process usually conducted only by giving students assignment through Whats App Group. Teachers are required to design a variative online learning, therefore students will not be bored (Yuangga \& Sunarsi, 2020). According to Andani \& Yulian (2018), book is an online media which can be developed, from a textbook into an electronic book or known well as E-Book which has a transition effect in every page displacement. Besides, students are lack of understanding values of local wisdom nowadays, especially Balinese local wisdom where the people act like western people as the effect of globalization. Children who do not have ability to filter and maintain their emotional stability maybe adapt into bad thing that they should not do like negative behavior and appearance they found in the internet (Gender et al., 2018). Moreover, elementary school students often forget to study, they are more interesting in using sophisticated technological tools. This issue was proven by students' middle semester score that tend to be low in social sciences subject, specifically $70 \%$ students only reach the standar of minimum completeness criteria (KKM). Furthermore, this issue indicates that there is a gap between a good social sciences learning process with the use of learning media that can impact on students' understanding. Therefore, an innovative online media which appropriate for the learning process is indispensable. According to Silmi \& Rachmadyanti (2018), choosing an appropriate media that suitable with students' characteristic can impact the success of the learning objectives.

E-Book which contained Balinese local wisdom developed in order to help students understand about the the material and local wisdom in this globalization era. E-Book stands for electronic book which compiled from a textbook, then it converted into a digital format and saved in certain format (Abidin \& Praherdhiono, 2019; Fathoni \& Marpanaji, 2018; Vince \& Muhtadi, 2019). Digital book presented the information in electronic form which contained collections of texts, pictures, audios and videos and it can be opened by using computer, laptop or even smartphone (Gaol et al., 2019; Setiawan et al., 2018). There are two types of E-Book, the first one is closed E-Book which only can be opened by using certain program called as E-Book reader and the second one is E-Book which can be read by using any digital equipment such as laptop and smartphone (Prabowo \& Heriyanto, 2013). In order to make elementary school students in Bali easier in using E-Book, therefore an E-Book in the second type has been developed and it also contains Balinese local wisdom.

Local wisdom are formulated as a view of life which became a tradition (ajeg) in a region which consist of the combination from God's values dan social values and it developed within society (Musanna, 2012). Every region has different local wisdom and its sustainability need to be maintained from negative effect of globalization (Tinja, 2017). The sustainability of local wisdom is very important to be maintained, because it can be used as a fortress to keep the value of culture and morality in a nation (Indrawan, 2020). A research which conducted by Pamungkas (2017) mentioned that planting local wisdom values in the learning process can affect students' creativity. Students can think as wide as they can in order to combine several ideas about understanding the concept of learning materials with local wisdom. The integration of local wisdom values into the learning material can escort students to the situation where they can feel culturally aware, recognize their region values and they are able to learn based on their experience in daily life (Hutama, 2016; Oktarina \& Ribuwati, 2018; Wijiningsih et al., 2017). Sriasih (2019) states that planting Balinese local wisdom values by using Tri Hita Karana can be used to strengthening and fostering the growth of education which rooted in local wisdom with a global perspective for future education.

This research is supported by the result of previous research which conducted by Sabtaningrum (2020) which developed an E-Book based on multicultural at elementary school level. The research showed the E-Book which has been developed is very effective and needed in the learning process. Besides, Setiawan (2018) developed a digital book or a 3D book, especially for social science material. The result of the study showed that the product which was produced is valid, effective and practical, therefore the product was proper to be used in the learning process. Furthermore, it is known that the use of digital 3D book can motivate students to learn, because in this technological development era students are more interesting with the learning process which use technological-based learning. Then, a research conducted by Idhamani (2020) mentioned that students are more interesting to read a text that available on the smartphone like on the E-Book, because there are a lot of texts which can arise students' interest to read. 
Furthermore, a research by Ramastuti (2018) showed that the use of social science learning material contained Balinese local wisdom values in social science subject is very effective to be done in order to increase the value of social concern and students' environmental ethics. Therefore, E-Book development contained Balinese local wisdom values is very effective and important to be done in this globalization era.

Based on aforementioned statements, this study aims to describe the process of E-Book development contained Balinese wisdom values and to discover the validation result of the E-Book based on experts, individual test and small group test.

\section{Method}

The design of this research was research and development. In this research, an E-Book has been developed by using ADDIE (Analyze, Design, Development, Implementation, Evaluation) development model. This model is arranged sistematically as an effort to solve the learning problems related with learning resource and it customizes to the needs and characteristics of students. Tegeh (2014) argued that there are five stages of ADDIE including analysis, design, development, implementation and evaluation. The subject of this research was one expert lecturer in lesson content, one expert lecturer in instructional design and learning media, individual test involving three students and small group test involving

In order to collect the data in this research, quesstionnaire method was used. Questionaire method was used in the product test through an expert of lesson content, expert of intructional design, expert of learning media, inividual test and small group test. The instrument which used to collect the data of this research was questionnaire. Therefore, the instrument grid of this research can be seen in the following section.

Table 1. Lesson Content Expert Instrument Grid

\begin{tabular}{|c|c|c|c|c|}
\hline No. & Aspect & Indicator & $\begin{array}{c}\text { Item } \\
\text { Number }\end{array}$ & $\begin{array}{l}\text { Total } \\
\text { Item }\end{array}$ \\
\hline \multirow{3}{*}{1.} & \multirow{3}{*}{ Curriculum } & a. Suitability of material with basic competencies & 1 & \multirow{3}{*}{3} \\
\hline & & b. Suitability of material with indicators & 2 & \\
\hline & & c. Suitability of material with learning objectives & 3 & \\
\hline \multirow{7}{*}{2.} & \multirow{7}{*}{ Material } & a. Suitability of material with student characteristics & 6 & \multirow{7}{*}{7} \\
\hline & & b. Depth of material & 4 & \\
\hline & & c. The material is supported by the right media & 8 & \\
\hline & & d. The material is easy to understand & 7 & \\
\hline & & e. The material represents real life & 9 & \\
\hline & & f. Provide another resource for learning & 5 & \\
\hline & & g. Use of appropriate and consistent language & 10 & \\
\hline \multirow{3}{*}{3.} & \multirow[b]{2}{*}{ Evaluation } & a. The suitability of the evaluation with the material & 12 & \multirow[b]{2}{*}{2} \\
\hline & & $\begin{array}{l}\text { b. The suitability of the difficulty level of the questions with } \\
\text { the competence }\end{array}$ & 11 & \\
\hline & & Total & & 12 \\
\hline
\end{tabular}

Table 2. Instructional Design Expert Instrument Grid

\begin{tabular}{|c|c|c|c|c|}
\hline No & Aspect & Indicator & $\begin{array}{c}\text { Item } \\
\text { Number }\end{array}$ & $\begin{array}{l}\text { Total } \\
\text { Item }\end{array}$ \\
\hline \multirow[b]{2}{*}{1} & \multirow[b]{2}{*}{ Purpose } & a. Clarity of learning objectives & 1 & \multirow[b]{2}{*}{2} \\
\hline & & $\begin{array}{l}\text { b. Consistency between objectives, materials, and } \\
\text { evaluation }\end{array}$ & 2 & \\
\hline \multirow{4}{*}{2} & \multirow{4}{*}{ Strategies } & a. Systematic delivery of material & 5 & \multirow{4}{*}{4} \\
\hline & & b. Be able motivate students & 4 & \\
\hline & & c. Provide attention grabbers & 3 & \\
\hline & & $\begin{array}{l}\text { d. Provide students with opportunities to study } \\
\text { independently }\end{array}$ & 6 & \\
\hline \multirow{2}{*}{3} & \multirow{2}{*}{ Evaluation } & $\begin{array}{l}\text { a. Provide evaluation questions to test student } \\
\text { understanding }\end{array}$ & 8 & \multirow{2}{*}{2} \\
\hline & & $\begin{array}{l}\text { b. The questions presented are in accordance with the } \\
\text { learning indicators }\end{array}$ & 7 & \\
\hline & & Total & & 8 \\
\hline
\end{tabular}


Table 3. Learning Media Expert Assessment Instruments Grid

\begin{tabular}{|c|c|c|c|c|}
\hline No & Aspect & Indicator & $\begin{array}{c}\text { Item } \\
\text { Number }\end{array}$ & $\begin{array}{l}\text { Total } \\
\text { Item }\end{array}$ \\
\hline \multirow{3}{*}{1.} & \multirow{3}{*}{ Tecnical } & a. The use of pictures in the E-Book supports learning & 1 & \multirow{3}{*}{$\mathrm{Km}$} \\
\hline & & $\begin{array}{l}\text { b. Use of videos that support understanding of the } \\
\text { material }\end{array}$ & 3 & \\
\hline & & c. Media can generate student motivation & 2 & \\
\hline \multirow[t]{2}{*}{2.} & \multirow[t]{2}{*}{ Display } & $\begin{array}{l}\text { a. Good display quality } \\
\text { b. The screen display is harmonious and balanced }\end{array}$ & $\begin{array}{l}4 \\
5\end{array}$ & \multirow[t]{2}{*}{2} \\
\hline & & a. The accuracy of using fonts & 8 & \\
\hline 3. & Text & b. The accuracy of using the font size & 7 & 3 \\
\hline \multirow[t]{2}{*}{4.} & $\begin{array}{l}\text { Picture } \\
\text { and Video }\end{array}$ & $\begin{array}{l}\text { a. The use of pictures in the E-Book supports learning } \\
\text { b. Use of videos that support understanding of the } \\
\text { material }\end{array}$ & $\begin{array}{c}9 \\
10\end{array}$ & 2 \\
\hline & & Total & & 10 \\
\hline
\end{tabular}

Table 4. Individual and Small Group Try-Out Instrument

\begin{tabular}{|c|c|c|c|c|}
\hline No & Aspect & Indicator & $\begin{array}{c}\text { Item } \\
\text { Number }\end{array}$ & $\begin{array}{l}\text { Total } \\
\text { Item } \\
\end{array}$ \\
\hline \multirow{4}{*}{1} & \multirow{4}{*}{$\begin{array}{l}\text { Display } \\
\text { Design }\end{array}$} & a. Attractiveness of E-Book display & 2 & \multirow{4}{*}{4} \\
\hline & & b. Text legibility & 1 & \\
\hline & & c. Image clarity & 4 & \\
\hline & & $\begin{array}{l}\text { d. Clarity of instructions for using links (Google } \\
\text { Form \& Youtube) }\end{array}$ & 3 & \\
\hline \multirow{4}{*}{2} & \multirow{4}{*}{ Material } & a. The material is easy to understand & 7 & \multirow{4}{*}{3} \\
\hline & & b. Clarity of material description & 6 & \\
\hline & & c. Media gives students enthusiasm in learning & 5 & \\
\hline & & a. Clarity of instructions for working on questions & 9 & \\
\hline \multirow[t]{3}{*}{3} & Evaluation & b. The questions are in accordance with the material & 10 & \multirow[t]{2}{*}{3} \\
\hline & & c. Language is easy to understand & 8 & \\
\hline & & Total & & 10 \\
\hline
\end{tabular}

(Source: Sudarma, 2015)

This development research was used decriptive quantitative analysis method. Descriptive quantitative analysis method is a method to process data by designing the data sistematically in the form of numbers and percentages in onder to obtain a general conclusion (Agung, 2014). This kind of analysis method was used in order to process the data which have been collected by using questionnaire in the form of Likert scale. Furthermore, the result of the percentages of each questionnaire have been converted in the scale five table in order to give meaning and decision-making of the appropriateness of the product developed.

\section{Result and Discussion}

The result of this development research found two main principals such as: (1) the design and development of the E-Book and (2) the validation of E-Book product. The design and development of this E-Book was used ADDIE development model. ADDIE consists of five stages namely, analysis, design, development, implementation and evaluation.

The first finding was in the analysis stage, especially the analysis of teacher and student needs in the learning process, analysis of learning materials and students' facility during the learning process. A learning media which can help students to learn independently during online learning was highly needed. All this time the learning process only focused on the use of textbook which obtained by the school, especially for social sciences subject and other media are rarely used. Besides, the learning material is given to students still too general and wide. Therefore, in order to deliver the material to students, it still needs to give them the real example which they might find in their real life, in order to make them easier to get the material. Based on the analysis of the data collection, it found that students were interest to 
learn by using innovative and practical media such as E-Book, learning videos with interesting pictures. Based on the analysis of the needs of teacher and student, an E-Book was developed which contained pictures, integrated YouTube videos, and self-evaluation questions for students. Based on the analysis, the school facilities already have LCD projectors, speakers, and WiFi. In addition, teachers and students are also used to using electronic media such as smartphones, laptops, and computers. Therefore, electronic media such as E-Book can be developed for online learning in accordance with student characteristics.

The second finding was at the design stage, a process was carried out to design a product before it has been developed, which includes activities (a) determining the hardware and software used such as laptop or PC, the Power Point 2013 application and Flip PDF Corporate, as well as online sites such as Youtube and Googleform, (b ) creating design of the E-Book such as the flowchart as a plot or a media path and a storyboard which contained the virtual design of the E-Book, descriptions, and text contained in the page E-Book, (c) outlining the content of the material in the media, (d) designing the media, (d) arranging learning activities, and (e) making a product assessment instrument in the form of a questionnaire used by the subjects of this study, who were the experts and students to determine the feasibility of the developed product.

The third finding was at the development stage, especially producing products to assessing products that have been developed by subjects to determine the level of product feasibility before being used in the learning process. The development stage starts from (a) preparing material on Microsoft Office Power Point, (b) collecting relevant images to the material through the google site, online thematic books, and other sources, (c) searching for relevant videos to the material through youtube site, (d) combining relevant images with the material in the Microsoft Office Power Point, (e) preparing the exercises of the material by using google form, (f) converting the file of the E-Book in Microsoft Office Power Point into PDF, (g) uploading E-Book file in the form of PDF into the Flip PDF Corporate application, (h) merging youtube video link and google form link on E-Book, and (i) publishing E-Book in the form of html and exe links. After the E-Book has been produced, the next is the implementation of product test on the test subjects, who were content experts, instructional design experts, instructional media experts, individual test, and small group test.

Findings on fourth stage was at the implementation stage. At the implementation stage, the product which has been developed should be applied into the learning process to determine the effectiveness of the product. However, due to the situation that did not allow the research to reach many students during the Covid-19 pandemic, the implementation stage could not be conducted. The last stage was the evaluation stage which was carried out formatively to measure or assess learning media products which include product validation from experts, individual test, and small group test.

Product validation was determined based on the results of product test by the subjects, who were lesson content expert, instructional design expert, instructional media expert and students through individual test, and small group test. This activity aims to determine the feasibility level of the product being developed. The instrument used to determine product validation was a questionnaire. The content of the lesson was assessed by a lesson content expert, who was a lecturer in social studies education namely, Drs. I Wayan Sujana, S.Pd., M.Pd. The design and learning media is rated by experts qualified faculty educational technology on behalf of Dr. I Made Tegeh S.Pd., M.Pd. Individual test with three students who reached high, medium, and low learning outcomes. Small group test with 12 students consisting of four students with high learning outcomes, four students with moderate learning outcomes, and four students with low learning outcomes at SD No. 1 Jagapati. Therefore, the results of the validation of the development of an E-Book containing the values of Balinese local wisdom based on experts and students as users can be seen as follows

Table 7. E-Book Product Try-Out Result Percentage Score

\begin{tabular}{clccc}
\hline No. & \multicolumn{1}{c}{ Subject } & Result (\%) & Qualification & Explanation \\
\hline 1. & Learning Content Expert & 87,50 & Good & Feasible, need a little revision \\
2. & Learning Design Expert & 100 & Very Good & Very feasible, no need to revise \\
3. & Learning Media Expert & 92,50 & Very Good & Very feasible, no need to revise \\
4. & Individual Try-out & 93,33 & Very Good & Very feasible, no need to revise \\
5. & Small Group Try-out & 94,16 & Very Good & Very feasible, no need to revise \\
\hline
\end{tabular}

Based on the results of product test that have been conducted by the content expert, the result of the percentage score was $87.50 \%$ with good qualifications. Instructional design expert got a percentage score of $100 \%$. Learning media experts obtained a percentage score of $92.50 \%$ with very good qualifications. The results of individual test obtained a score percentage of $93.33 \%$ with very good 
qualifications. The results of the small group test obtained a percentage score of $94.16 \%$ with very good qualifications. From the test results, it can be concluded that the product developed is suitable for being use in the learning process. However, in the product testing process there were also comments and suggestions from the experts which can be taken into consideration for product improvement. Below is a summary of comments and suggestions provided by experts and test subjects.

Table 8. Comments and Revisions

\begin{tabular}{|c|c|c|c|}
\hline No. & Respondents & Comment & Revision \\
\hline \multirow[t]{2}{*}{1.} & Learning Content Expert & $\begin{array}{l}\text { Use the picture which can } \\
\text { describe Balinese local } \\
\text { wisdom }\end{array}$ & $\begin{array}{l}\text { Changing the pictures with suitable } \\
\text { pictures as Balinese local wisdom }\end{array}$ \\
\hline & & $\begin{array}{l}\text { Use an evaluation exercise } \\
\text { which can make students } \\
\text { think in higher order } \\
\text { thinking skill }\end{array}$ & $\begin{array}{l}\text { Changing the evaluation exercise } \\
\text { into higher level }\end{array}$ \\
\hline \multirow[t]{3}{*}{2.} & Learning Design Expert & $\begin{array}{l}\text { Give number and tittle for } \\
\text { the tabel }\end{array}$ & $\begin{array}{l}\text { Giving number and tittle in each } \\
\text { tabel }\end{array}$ \\
\hline & & $\begin{array}{l}\text { Sources and the tittle of the } \\
\text { pictures need to be included }\end{array}$ & $\begin{array}{l}\text { Include the source and title of the } \\
\text { image }\end{array}$ \\
\hline & & $\begin{array}{l}\text { The text need to be moved } \\
\text { to the center to create space }\end{array}$ & $\begin{array}{l}\text { Moving the text to the center and } \\
\text { create the space }\end{array}$ \\
\hline \multirow[t]{2}{*}{3.} & Learning Media Expert & $\begin{array}{l}\text { The contrast is needed in the } \\
\text { pages ii }\end{array}$ & $\begin{array}{l}\text { Changing the text color to create } \\
\text { contrast with the background }\end{array}$ \\
\hline & & $\begin{array}{l}\text { Add the supervisor identity } \\
\text { and thanking expression at } \\
\text { the end of the product }\end{array}$ & $\begin{array}{l}\text { Adding supervisor identity and } \\
\text { thanking expression at the end of } \\
\text { the product }\end{array}$ \\
\hline
\end{tabular}

The display of the E-Book product development contained character values in the social science lesson content for $4^{\text {th }}$ grade elementary school can be seen as follows.

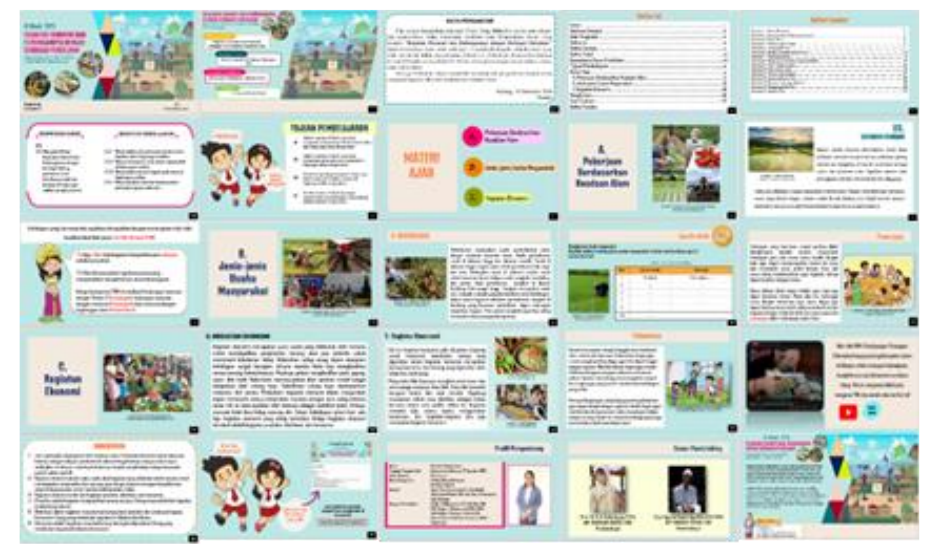

Gambar 1. Hasil akhir E-Book

\section{Discussion}

Based on the results of the research that has been done, the development of an E-Book containing local Balinese religious values is very well qualified and suitable to be used in the learning process, because in the development process itw was conducting by using ADDIE development model.

The review result of social science content expert obtained good qualification. The content or materials in the E-Book were easy to be understood by students, because the E-Book developed was associated with the environment around students, therefore it can represent real life. It can make students more interested and motivate students to learn the material. Surely, this is supported by research that existed before. According Widiastuti (2017) as a source of learning, environment is very beneficial for students to learn about social science. Environmental potential can be in the form of social, economic, cultural and geographic environments. The material presentation can be assisted with a pictures and videos which are relevant to the material, to facilitate students in order to obtain information (Pribadi, 
2017; Cecep \& Daddy, 2020). The choice of material also have to be in accordance with the learning and evaluation objectives used. The evaluation test used have to make students think at a high level to train students' critical thinking skills (Setiyoaji et al., 2020).

The review result of instructional design experts gained excellent qualifications. Instructional design assessment refers to the design of learning implementation, therefore learning activities can run systematically and efficiently. According to Dick \& Reiser (Ningrum, 2015) the design of the learning process is a systematic process for designing, developing, implementing and evaluating an instruction to improve the quality of education in order to fill student learning needs according to cognitive development and fun for students. A developed E-Book is adjusted with the characteristics of the students, therefore students can learn in a comfortable and fun way. This is supported by previous research, Nehru \& Syarkowi (2017) stated that in order to make students can achieve success in the future, the teacher has an obligation to provide what students need in the learning process in accordance with student characteristics.

As a result of the review from instructional media expert, it is known that E-Books containing the values of Balinese local wisdom got very good qualifications. The E-Book developed included pictures and videos that can help students understand the material easily. The attractive learning media contained images, video, audio, animation can improve students' memory (Dadi, 2019; Aeni, 2019). In addition, the type of letter, font size, and language used are also in accordance with the characteristics of students. This is in accordance with one of the main principles of motivation in text and image design, namely the readability of the text with simple language and easy to understand (Sudarma, 2015). The E-Books which developed by the help of technology and information tools strongly support students and teachers in implementing online learning from home (Ding, 2020).

After passing the expert's review, then the product was tried out on students through individual test and small group test which got very good qualification. The product developed is in accordance with student interests because it can be accessed easily via a smartphone. According to Hisbiyati \& Khusnah, (2017), the application of innovative learning media is an effort to take advantage of students' interest in using smartphones to keep learning. Through E-Books that can be accessed via smartphones, it can make learning time became effective and efficient, besides it is also fun for students to learn. E-books or digital books are easy to carry around, can be stored on a smartphone and do not require large storage space (Ruddamayanti, 2019; Waryanto, 2017).

From the research result discussions, the E-Book media contained the values of Balinese local wisdom is suitable for use in social sciences learning. The selection of E-Book media in the learning process is very appropriate. This is supported by research conducted by Fitria (2017) which stated that EBook can increase learning productivity. In addition, research by Arnesti \& Hamid (2015), mentioned that the use of online learning media such as E-Book can provide advantages such as, independent learning and high interactivity. Based on the research that has been done, it is believed the E-Book contained the values of Balinese local wisdom, can help teachers in delivering material, helping students understand the material, and can instill the values of local wisdom for students in globalization era. The implication of using E-Books as learning media in schools requires several supporting facilities such as internet access, computers, laptops, smartphone and the ability of teachers or students to access E-Books.

\section{Conclusion}

The product of the E-Book development contained the values of Balinese local wisdom is "appropriate" to be used in the learning content social science subject for $4^{\text {th }}$ grade elementary school students. This is because the product developed can facilitate students to learn, in accordance with the characteristics of students, equipped with a text that is easy to be read and accompanied by pictures and videos which are interesting, as well as to foster the values of local wisdom of Bali.

\section{References}

Abidin, Z., \& Praherdhiono, H. (2019). Pengembangan Media Pembelajaran E-Book Infografis Sebagai Penguatan Kognitif Siswa X MIA. Jurnal Kajian Teknologi Pendidikan, 2(1), 37-44. https://doi.org/10.17977/um038v2i12019p037.

Aeni, S., Sutrisno, S., \& Mushafanah, Q. (2019). Pengembangan Media KOPER (Kotak Permainan) pada Tema 7 Kebersamaan. Jurnal Penelitian Dan Pengembangan Pendidikan, 3(3), 159. https: //doi.org/10.23887/jppp.v3i3.18158.

Agung, A. A. G. (2014). Metodologi Penelitian Pendidikan. Aditya Media Publishing.

Andani, D. T., \& Yulian, M. (2018). Pengembangan Bahan Ajar Electronic Book Menggunakan Software 
Kvisoft Flipbook Pada Materi Hukum Dasar Kimia di SMA Negeri 1 Panton Reu Aceh Barat. Jurnal IPA \& Pembelajaran IPA, 2(1), 1-6. https://doi.org/10.24815/jipi.v2i1.10730.

Arnesti, N., \& Hamid, A. (2015). Penggunaan Media Pembelajaran Online - Offline Dan Komunikasi Interpersonal Terhadap Hasil Belajar Bahasa Inggris. Jurnal Teknologi Informasi \& Komunikasi Dalam Pendidikan, 2(1). https://doi.org/10.24114/jtikp.v2i1.3284.

Budiyono, B. (2020). Inovasi Pemanfaatan Teknologi Sebagai Media Pembelajaran di Era Revolusi 4.0. Jurnal Kependidikan: Jurnal Hasil Penelitian Dan Kajian Kepustakaan Di Bidang Pendidikan, Pengajaran Dan Pembelajaran, 6(2), 300. https://doi.org/10.33394/jk.v6i2.2475.

Cecep, K., \& Daddy, D. (2020). Pengembangan Media Pembelajaran. Kencana.

Dadi, I. K., Redhana, I. W., \& Juniartina, P. P. (2019). Analisis Kebutuhan Untuk Pengembangan Media Pembelajaran Ipa Berbasis Mind Mapping. Jurnal Pendidikan Dan Pembelajaran Sains Indonesia (JPPSI), 2(2), 70. https://doi.org/10.23887/jppsi.v2i2.19375.

Ding, J., Hermawati, D., \& Subakti, H. (2020). Analisis Media Pembelajaran Daring Di Era Pandemi Covid-19 Pada Kelas III SD Negeri 027 Samarinda Ulu. Sistema: Jurnal Pendidikan, 01(02), 16-23. https://doi.org/10.24903/sjp.v1i2.639.

Fathoni, M. I., \& Marpanaji, E. (2018). Pengembangan e-book interaktif mata pelajaran teknologi informasi dan komunikasi (TIK) untuk SMK kelas X. Jurnal Inovasi Teknologi Pendidikan, 5(1), 70-81. https://doi.org/10.21831/jitp.v5i1.17149.

Fitria, T. N., \& Heliawan, Y. A. (2017). Meningkatkan Kemampuan Mahasiswa Prodi S1 Akuntansi Dalam Memahami Buku, Ebook Dan Artikel/Jurnal Akuntansi Berbahasa Inggris. Jurnal Akuntansi Dan Pajak, 17(02), 1-13. https://doi.org/10.29040/jap.v17i02.10.

Gaol, M. L., Serevina, V., \& Supriyati, Y. (2019). Media Pembelajaran E-Book Berbasis 3D PageFlip Pada Materi Suhu dan Kalor dengan Model Pembelajaran Discovery Learning. Prosiding Seminar Nasional Fisika, VIII, 319-324. https://doi.org/10.21009/03.snf2019.01.pe.40.

Hidayat, H., Mulyani, H., Nurhasanah, S. D., Khairunnisa, W., \& Sholihah, Z. (2020). Peranan Teknologi Dan Media Pembelajaran Bagi Siswa Sekolah Dasar Di Dalam Pembelajaran Pendidikan Kewarganegaraan. Jurnal Pendidikan Kewarganegaraan Undiksha, 8(2), 35-46. https://doi.org/10.23887/jpku.v8i2.24759.

Hisbiyati, H., \& Khusnah, L. (2017). Penerapan Media E-Book Berekstensi Epub Untuk Meningkatkan Minat Dan Hasil Belajar Siswa SMP Pada Mata Pelajaran IPA. Jurnal Pena Sains, 4(1), 16. https://doi.org/10.21107/jps.v4i1.2775.

Hutama, F. S. (2016). Pengembangan Bahan Ajar Ips Berbasis Nilai Budaya Using Untuk Siswa Sekolah Dasar. JPI Uurnal Pendidikan Indonesia), 5(2), 113. https://doi.org/10.23887/jpiundiksha.v5i2.8359.

Idhamani, A. P. (2020). Dampak Teknologi Informasi terhadap Minat Baca Siswa. UNILIB: Jurnal Perpustakaan, 11(1), 35-41. https://doi.org/10.20885/unilib.vol11.iss1.art4.

Indrawan, I. P. O., Sudirgayasa, I. G., \& ... (2020). Integrasi Kearifan Lokal Bali di Dunia Pendidikan. Prosiding Webinar ..., 3, 189-194.

Kuswanto, J., \& Radiansah, F. (2018). Media Pembelajaran Berbasis Android Pada Mata Pelajaran Sistem Operasi Jaringan Kelas XI. Jurnal Media Infotama, 14(01), 129. https://doi.org/10.37676/jmi.v14i1.467.

Maulidiyah, E. C. (2018). Penanaman nilai-nilai agama dalam pendidikan anak di era digital. Martabat, 2(1), 71-90. https://doi.org/10.21274/martabat.2018.2.1.71-90.

Musanna, A. (2012). Untuk Mempersiapkan Guru Yang Memiliki Kompetensi Budaya Articulation of Teacher Education Based on Local Wisdom. Jurnal Pendidikan Dan Kebudayaan, 18(3), 328-341. https://doi.org/10.24832/jpnk.v18i3.92.

Nehru, N., \& Syarkowi, A. (2017). Analisis Desain Pembelajaran Untuk Meningkatkan Literasi Sains Berdasarkan Profil Penalaran Ilmiah. WaPFi (Wahana Pendidikan Fisika), 2(1), 20-24. https://doi.org/10.17509/wapfi.v2i1.4867.

Ningrum, D. S., \& Leonard, L. (2015). Pengembangan Desain Pembelajaran Matematika Sekolah Dasar Kelas 1. Formatif: Jurnal Ilmiah Pendidikan MIPA, 4(3), 163-173. https://doi.org/10.30998/formatif.v4i3.151.

Nurrita, T. (2018). Pengembangan media pembelajaran untuk meningkatkan hasil belajar siswa. MISYKAT: Jurnal Ilmu-Ilmu Al-Quran, Hadist, Syari'ah Dan Tarbiyah, 3(1), 171. https://core.ac.uk/download/pdf/268180802.pdf.

Oktarina, R., \& Ribuwati, R. (2018). Penerapan Pendidikan Berbasis Kearifan Lokal Di Sd Negeri 8 Rambutan Kabupaten Banyuasin Menuju Global Citizen. Journal of Chemical Information and Modeling, $\quad$ 53(9), 287.2 https://jurnal.univpgripalembang.ac.id/index.php/Prosidingpps/article/view/1882. 
Pamungkas, A., Subali, B., \& Linuwih, S. (2017). Implementasi model pembelajaran IPA berbasis kearifan lokal untuk meningkatkan kreativitas dan hasil belajar siswa. Jurnal Inovasi Pendidikan IPA, 3(2), 118. https://doi.org/10.21831/jipi.v3i2.14562.

Prabowo, A., \& Heriyanto, H. (2013). Analisis Pemanfaatan Buku Elektronik (E-Book) Oleh Pemustaka di Perpustakaan SMA Negeri 1 Semarang. Jurnal Ilmu Perpustakaan, 2(2), 1-9. https://ejournal3.undip.ac.id/index.php/jip/article/view/3123.

Pribadi, B. A. (2017). Media dan Teknologi dalam Pembelajaran. Prenada Media Group.

Ramastuti, N. W., Atmaja, N. B., \& Lasmawan, I. W. (2018). Pengembangan Bahan Ajar Ips Berbentuk Handout Bermuatan Kearifan Lokal Bali Untuk Meningkatkan Nilai Peduli Sosial Dan Etika Lingkungan. Jurnal Pendidikan IPS Indonesia, 2(1), 12-21. https://doi.org/10.23887/pips.v2i1.2858.

Ruddamayanti, R. (2019). Pemanfaatan Buku Digital Dalam Meningkatkan Minat Baca. Prosiding Seminar Nasional Pendidikan Program Pascasarjana Universitas PGRI Palembang, 2, 364-370. https://jurnal.univpgri-palembang.ac.id/index.php/Prosidingpps/article/view/2750.

Sabtaningrum, F. E., Wiyokusumo, I., \& Leksono, I. P. (2020). E-book Tematik Terpadu Berbasis Multikultural Dalam Kegiatan SFH (School from Home). Jurnal Ilmiah Sekolah Dasar, 4(2), 153. https://doi.org/10.23887/jisd.v4i2.24796.

Saodah, S., Amini, Q., Rizkyah, K., Nuralviah, S., \& Urfany, N. (2020). Pengaruh Globalisasi Terhadap Siswa Sekolah Dasar. Jurnal Pendidikan Dan Dakwah, 2(3), 375-385. https://doi.org/10.36088/pandawa.v2i3.907.

Setiawan, D. A., Wahjoedi, W., \& Towaf, S. M. (2018). Multimedia Interaktif Buku Digital 3D. Jurnal Pendidikan, 3(9), 1133-1141. https://doi.org/10.17977/jptpp.v3i9.11532.

Setiyoaji, W. T., Supriana, E., \& Laksono, Y. A. (2020). Pengembangan E-Book Berbasis Android dengan Soal HOTS untuk Membantu Menganalisis Besaran Pada Materi Gerak Lurus. Jurnal Pendidikan Fisika Dan Teknologi, 6(1), 114. https://doi.org/10.29303/jpft.v6i1.1725.

Silmi, M. Q., \& Rachmadyanti, P. (2018). Pengembangan Media Pembelajaran Video Animasi Berbasis Sparkol Videoscribe Tentang Persiapan Kemerdekaan Ri Sd Kelas V. Jurnal Penelitian Pendidikan Guru Sekolah Dasar, 6(4). https://jurnalmahasiswa.unesa.ac.id/index.php/jurnal-penelitianpgsd/article/view/23611.

Sriasih, S. A. P., Budasi, I. G., Nitiasih, P. K., \& Wisudariani, N. M. R. (2019). Strategi Pembelajaran Berorientasi Konsep Tri Hita Karana Pada Fakultas Bahasa Dan Seni Universitas Pendidikan Ganesha. Jurnal IKA, 17(2), 109-127. https://doi.org/10.23887/ika.v17i2.19843.

Suartama, I. K. (2019). Bahan Ajar: Evaluasi dan Kriteria Kualitas Multimedia Pembelajaran. Universitas Pendidikan Ganesha.

Sudarma, I. K., Teguh, I. M., \& Prabawa, D. G. A. P. (2015). Desain Pesan Kajian Analitis Desain Visual Teks dan Image. Graha Ilmu.

Supriyono. (2018). Pentingnya Media Pembelajaran Untuk Meningkatkan Minat Belajar Siswa SD. Edustream: Jurnal Pendidikan Dasar, 2(1), 43-48. https://journal.unesa.ac.id/index.php/jpd/article/view/6262.

Tegeh, I. M. (2014). Model Penelitian Pengembangan. Graha Ilmu.

Tinja, Y., Towaf, S. M., \& Hariyono, H. (2017). Pengembangan Bahan Ajar Tematik Berbasis Kearifan Lokal Sebagai Upaya Melestarikan Nilai Budaya Pada Siswa Sekolah Dasar. Jurnal Pendidikan: Teori, Penelitian, Dan Pengembangan, 2(9), 1257-1261. https://doi.org/10.17977/jptpp.v2i9.9990.

Vince, M., \& Muhtadi, A. (2019). Pengembangan Buku Digital Interaktif Matematika pada Materi Geometri. Jurnal Inovasi Teknologi Pendidikan, 6(2), 196-207. https://doi.org/10.21831/jitp.v6i2.26809.

Waryanto, N. H., Marwoto, B. S. H., Hernawati, K., Emut, E., \& Insani, N. (2017). Pelatihan Pembuatan Buku Elektronik Interaktif. Jurnal Pengabdian Masyarakat MIPA Dan Pendidikan MIPA, 1(1), 33-40. https://doi.org/10.21831/jpmmp.v1i1.12971.

Widiastuti, E. H. (2017). Pemanfaatan Lingkungan .Sebagai Sumber Pembelajaran Mata Pelajaran IPS. Satya Widya, 33(1), 29. https://doi.org/10.24246/j.sw.2017.v33.i1.p29-36.

Wijiningsih, N., Wahjoedi, W., \& Sumarmi, S. (2017). Pengembangan Bahan Ajar Tematik Berbasis Budaya Lokal. Jurnal Pendidikan: Teori, Penelitian, Dan Pengembangan, 2(8), 1030-1036. https://doi.org/10.17977/jptpp.v2i8.9760.

Yuangga, K. D., \& Sunarsi, D. (2020). Pengembangan media dan strategi pembelajaran untuk mengatasi permasalahan pembelajaran jarak jauh di pandemi covid-19. JGK (Jurnal Guru Kita), 4(3), 51-58. https://doi.org/10.24114/jgk.v4i3.19472. 